УКРАЇНСЬКИЙ ФОЛЬКЛОР ЯК ЗАСІБ ФОРМУВАННЯ ДІАЛОГІЧНОЇ КОМПЕТЕНТНОСТІ УЧНІВ ПОЧАТКОВОЇ ШКОЛИ

\title{
UKRAINIAN FOLKLORE AS A MEAN FOR FORMING DIALOGICAL COMPETENCE OF PRIMARY SCHOOL PUPILS
}

Стаття присвячена проблемі використання українського фолььклору задля формування діалогічної компетентності молодших школярів. З'ясовано, що особливо складною й багатоаспектною є проблема мовленнєвого розвитку молодших школярів, адже саме в молодшому шкільному віці формуються основи мовно-мовленнєво компетентності й ознаки національномовної особистості. Наголошено, що Концепція Нової української школи спрямована на фрормування комунікативної компетентності молодших школярів. Акцентовано увагу на тому, що, незважаючи на численні дослідження мовленнєвого розвитку молодших школярів засобами фрольклору, доцільність використання цих засобів $у$ мовленнєвій діяльності учнів початково школи потребує належного та ґрунтовного висвітлення. Розглянуто френомен «діалогічне мовлення», що трактується як фрорма усного мовлення, комунікативний акт, у якому має місце зміна ролей мовия і слухача, він протікає в певній ситуації та $\epsilon$ ї продуктом. Зазначено, що особливістю діалогічного мовлення $є$ те, що воно тісніше, ніж монологічне, пов'язане із ситуацією. Саме це й зумовлює специфріку лінгвістичної будови діалогу: часто зустрічаються згорнуті (редуковані) фрорми, скорочені речення тощо. Уточнено, що діалогічне мовлення завжди більше насиченим позамовними засобами спілкування (міміка, інтонація, сила голосу, жести тощо), за допомогою яких мовець висловлює при пущення, обурення, жаль тощо. Наголошено, що важливе місце в системі засобів мовленнєвого розвитку, зокрема діалогічного мовлення, посідає фрольклор. Підкреслено, що аналіз малих фрольклорних фрорм засвідчив, що їм притаманна низка специфрічних рис, які надзвичайно приваблюють дитину, а саме: невеликий обсяг тексту, доступність змісту, захоплюючий ігровий сюжет, використання художньо-зображальних засобів мови. Фольклорні твори відзначаються барвистістю, виразністю, ритмічністю, легкістю для запам'ятовування. Доведено, що використання фольклору, його різноманітних жанрів $є$ ефрективним засобом $i$ важливим чинником успішного навчання дітей діалогічного мовлення. Визначено перспективи подальших досліджень у цьому напрямі.
Ключові слова: діалог, діалогічне мовлення, діалогічна компетентність, український фольклор, молодші школярі.

The article is devoted to the problem of using Ukrainian folklore for the formation of dialogical competence of younger students. It has been found that the problem of speech development of younger students is especially difficult and multidimensional, since it is at a younger school age that the basics of linguistic competence and characteristics of a national-linguistic personality are formed. It is emphasized that the Concept of the New Ukrainian School is aimed at shaping the communicative competence of younger students. Attention is drawn to the fact that, despite the numerous studies of the vocal development of younger pupils by folklore, the expediency of using these facilities in the vocational activity of elementary school students requires proper and thorough coverage. The phenomenon of "dialog speech", which is interpreted as a form of oral speech, is a communicative act in which the role of the speaker and the listener changes, it takes place in a certain situation and is its product. The author notes that the peculiarity of dialogic speech is that it is more closely related to the situation than monologues. This is what determines the specifics of the linguistic structure of the dialogue: often reduced (reduced) forms, short sentences, etc. are found. It is clarified that dialogic speech is increasingly saturated with non-standard means of communication (facial expressions, intonation, voice, gestures, etc.), by which the speaker expresses suggestion, indignation, regret, etc. The author notes that folklore occupies an important place in the system of means of speech development, in particular dialogic speech. The author emphasizes that the analysis of small folk forms showed that they have a number of specific features that are extremely attractive to the child, namely: small volume of text, accessibility of content, fascinating game plot, use of artistic and depictive means of language. Folklore works are distinguished by their color, expressiveness, rhythm, ease of remembering. It is proved that the use of folklore, its various genres is an effective tool and an important factor in the successful learning of children in dialogic speech. The prospects for further research in this area are identified.

Key words: dialogue, dialogic speech, dialogic competence, Ukrainian folklore, junior students.
ДВНЗ «Прикарпатський національний університет імені Василя Стефаника»
Постановка проблеми в загальному вигляді.
овлення - один із найважливіших показників Мовлення - один із найважливіших показників бливо складною й багатоаспектною є проблема мовленнєвого розвитку молодших школярів, адже саме в молодшому шкільному віці фрормуються основи мовно-мовленнєвої компетентності та ознаки національно-мовної особистості.

Розбудова України як вільної демократичної держави, становлення й розвиток громадянського суспільства неможливі без якісної підготовки молодших школярів, їх соціалізації. Безперечно, у цьому процесі вільне володіння українською мовою є вкрай важливим. Сьогодні Концепція Нової української школи спрямована на фрормування комунікативної компетентності молодших школярів. У соціокультурній змістовій лінії початкової мовної освіти передбачено використання в мовленні зразків усної народної творчості, а отже, дослідження діалогічного мовлення молодших 
школярів засобами фольклору $є$ одним із актуальних завдань у системі початкової мовної освіти.

Аналіз останніх досліджень і публікацій. Проблема усного мовлення розглядалася психологами (Л. Виготський, Г. Кучинський, О. Лурія, С. Рубінштейн та ін.), психолінгвістами (С. Беркер, В. Виноградов, Е. Вільчек, О. Земська, І. Святогор, О. Сиротиніна, Л. Якубінський, Я. Яноушек та ін.), лінгводидактами (А. Богуш, М. Вашуленко, І. Зимня, Т. Ладиженська, М. Львов, Н. Озерова, Н. Сентюріна, В. Скалкін, О. Тимошенко, Л. Фесенко та ін.).

Методика розвитку мовлення - в центрі дослідження низки науковців (Л. Варзацька, М. Вашуленко, О. Мельничайко, К. Пономарьова, О. Хорошковська та ін.). Психологами (Л. Виготський, Д. Єльконін, О. Леонтьєв, С. Максименко та ін.) обґрунтовано основні положення діяльнісного підходу до проблеми розвитку мовлення.

Проблема навчання діалогічного мовлення була предметом досліджень багатьох лінгвістів (Н. Гез, М. Ляховська, Є. Пассов, В. Скалкін, л. щерба та ін.) та лінгводидактів (М. Вашуленко, Л. Вознюк, Н. Луцан, М. Пентелюк, А. Чулкова й ін.).

Вивчався плив народознавчих засобів на мовленнєвий розвиток дошкільника (Л. Березовська, С. Ласунова, Н. Луцан, О. Трифронова та ін.), молодшого школяра (Л. Соловець), учня середньої ланки школи (Н. Голуб, Л. Кожуховська, Т. Левченко й ін.).

Виділення не вирішених раніше частин загальної проблеми. Сьогодні як ніколи зростає інтерес та увага науковців до проблем зв'язку національного виховання, народної педагогіки, етнопедагогіки 3 професійною підготовкою майбутніх фрахівців у вищих навчальних закладах. Про це свідчать дослідження О. Березюк, О. Вишневського, Г. Волкова, О. Духновича, В. Кононенка, Л. Кравченка, Г. Лозко, Л. Маєвської, Ю. Махмутова, В. Мосіященка, М. Стельмаховича, В. Струманського, Є. Сявавко та ін.

Однак аналіз наукових праць засвідчив, що, незважаючи на численні дослідження мовленнєвого розвитку молодших школярів засобами фольклору, доцільність використання цих засобів у мовленнєвій діяльності учнів початкової школи потребує належного та ґрунтовного висвітлення.

Мета статті полягає в обґрунтування важливості використання українського фольклору задля формування діалогічної компетентності молодших школярів.

Виклад основного матеріалу. Державний стандарт початкової освіти передбачає, що поряд із лінгвістичною підготовкою діти повинні набути достатній особистий досвід культури спілкування й співпраці в різних видах діяльності. Розвиток діалогічного мовлення молодших школярів $€$ актуальною проблемою сучасної лінгводидактики, оскільки перед школою постало завдання формування мовно-творчої особистості, здатної приймати нестандартні рішення, творчо виражати думку.

На думку М. Вашуленка, сучасний процес удосконалення змісту й методів навчання української мови в початковій школі ґрунтується на нових досягненнях лінгвістичної науки, зокрема теорії тексту, а також психолінгвістики, предметом вивчення якої $€$ закономірності сприйняття і породження висловлювань. Учений уважає що вони лягли в основу розвитку зв'язного мовлення школярів, яке до цього переважно спиралося на інтуїцію, мовне чуття, найчастіше на зразок. Саме теорія мовленнєвої діяльності послугувала поштовхом для нових досліджень мовленнєвого розвитку дошкільників, молодших учнів, підлітків; її основні ідеї, пов'язані 3 чотирма фразами зв'язного висловлювання, стали активно застосовуватися методистами в навчанні мови [2].

У сучасній науковій літературі терміни «діалог», «діалогічне мовлення», «діалогічне спілкування» мають ідентичне значення та $€$ взаємозамінниками, оскільки діалогічне мовлення й діалогічне спілкування розглядаються як комунікативний акт, якому властива зміна ролей слухача та мовця. Обмін висловлювання відбувається так, що за допомогою їх послідовно-часової низки створюються діалогічні тексти (діалоги) для досягнення певної мовленнєвої мети [4, с. 73]. Діалог - це «форма мовлення, що характеризується зміною висловлювань двох або декількох (полілог) мовців (співрозмовників), безпосереднім зв'язком висловлювань із ситуацією» [4, с. 74]. Діалог, за словами В. Скалкіна, - це фрорма усного мовлення, комунікативний акт, у якому має місце зміна ролей мовця та слухача, він протікає в певній ситуації і $€$ ії продуктом [6, с. 6].

Поняття «діалогічне мовлення» - це об'єднане ситуативно-тематичною спільністю й комунікативними мотивами сполучення усних висловлювань, послідовно породжених двома та більше співрозмовниками в безпосередньому акті спілкування [6, с. 6]; «особливий вид мовленнєвої діяльності, фрункції якої реалізуються в процесі безпосереднього спілкування між співрозмовниками в результаті послідовного чергування стимулювальних і регулювальних реплік» [5, с. 9].

У лінгвістичних словниках зазначається, що «діалогічне мовлення - мовлення у формі бесіди, розмова, в якій бере участь не менше двох осіб» [3, с. 51]. Підкреслюється, що особливістю діалогу $€$ взаємозумовленість синтаксичної будови реплік співрозмовників, що об'єднує діалог у єдине ціле.

Учені (А. Богуш, М. Львов, В. Скалкін та ін.) визначають діалог як фрорму усного мовлення, розмову між двома співрозмовниками, що складається із запитань і відповідей. Діалог - це ланцюг реплік, які породжуються в процесі спілкування двох або 
декількох осіб, тому в діалогічному мовленні найбільш яскраво виявляється фрункція мовлення як засобу спілкування [181, с. 140]. Традиційно вчені (О. Бігіч, Т. Олійник, Н. Скляренко) визначають чотири комунікативні фрункції, що виконує діалогічне мовлення: запит інформації - повідомлення інформації; пропозиція (у формі прохання, наказу, поради) - прийняття або неприйняття запропонованого; обмін судженнями, враженнями, думками; взаємопереконання, обґрунтування свого погляду.

Особливістю діалогічного мовлення $€$ також те, що воно тісніше, ніж монологічне, пов'язане із ситуацією. Саме це й зумовлює специфіку лінгвістичної будови діалогу: часто зустрічаються згорнуті (редуковані) фрорми, скорочені речення тощо. Поза мовленнєвою ситуацією вони не завжди зрозумілі. Діалогічне мовлення $€$ більш уживаним, ніж монологічне, і ґрунтується на двох системах зв'язків - на зв'язку із ситуацією й на логічному зв'язку з попередньою фразою. Воно також вирізняється порівняно високою модальністю. Таке спілкування містить у собі не лише зміст висловлювання, а й певні оцінні характери стики того, про що йдеться. Кожен із учасників діалогу висловлює своє ставлення до предмета розмови, до позиції другого учасника. Діалогічне мовлення $€$ завжди більше насиченим позамовними засобами спілкування (міміка, інтонація, сила голосу, жести тощо), за допомогою яких мовець висловлює припущення, обурення, жаль тощо. Тому в цьому аспекті діалогічне мовлення легше, ніж монологічне. Навчання учнів діалогічного мовлення здійснюється поетапно: від відтворення зразка до самостійної побудови діалогу. Із цією метою доцільно використовувати завдання на відтворення, розігрування діалогів з прочитаних казок, оповідань; доповнення незавершеного діалогу; побудову діалогу за зразком; складання діалогу з опорою на допоміжні матеріали; побудову діалогу за ситуативним малюнком; створення діалогу за описаною ситуацією.

Важливе місце в системі засобів мовленнєвого розвитку, зокрема діалогічного мовлення, посідає фольклор. Його вплив на мовну освіту дітей розкрито в роботах видатних учених, педагогів, письменників (О. Духнович, С. Русова, Г. Сковорода, І. Срезневський, Є. Тихеєва, К. Ушинський, І. Франко й ін.). Питання щодо використання творів українського фольклору в процесі навчання дітей рідної мови розглядалося й сучасними науковцями (А. Богуш, В. Кононенко, М. Стельмахович та ін.).

Так, М. Стельмахович уперше в сучасній етнопедагогіці виокремлює таку її галузь, як народна дидактика. Заслуга народної дидактики, за вченим, полягає в тому, що вона передає кожному поколінню знання, які нагромадив народ за свою багатовікову історію. Кожен майбутній громадя- нин має засвоїти певну суму знань, умінь і навичок, і серед них у поле зору народної дидактики, як уважає М. Стельмахович, потрапляє насамперед засвоєння рідної мови, адже саме через рідну мову входить дитина у сореру людського спілкування, через мову усвідомлюється пізнання довкілля й духовний розвиток особистості. Тому й учіння дитини починається 3 вивчення рідної мови. На думку М. Стельмаховича, дитина, засвоюючи «материнську» мову, водночас ознайомлюється з усною народною творчістю, фольклор, як зазначає вчений, - «це не тільки засіб розвитку мовлення, а й активний поширювач знань 3 історії народу» [7, с. 228]. Виходячи 3 того що вдосконалення мовлення триває впродовж усього життя людини, народна дидактика виробила свій погляд на мову як на динамічну систему, яка не виникає одразу, а фрормується поступово. Таке трактування проблеми, на глибоке переконання М. Стельмаховича, «цілком закономірно привело до практичного ії втілення у створення дитячої мови як першого, підготовчого, етапу на шляху мовного розвитку дитини» [7, с. 245]. На думку вченого, дитяча мова $€$ «основним словесним засобом народної дидактики» [7, с. 245], який допомагає дитині пізнавати довкілля, опановувати рідну мову. Саме тому найціннішим засобом у мовленнєвому розвитку дитини є дитячий фрольклор (лічилки, скоромовки, дражнилки, мирилки тощо), який, на думку М. Стельмаховича, має не тільки «високу педагогічну ефективність», а й «значно прискорює мовний розвиток дитини» [7, с. 247]. Учений наголошує, що слухання й переказування народних казок, легенд, оповідань, запам'ятовування прислів'їв і приказок, уживання афоризмів, декламування дитячих поезій і виконання пісень, відгадування загадок тощо - це чудові уроки рідної мови [7].

Слушними $є$ поради А. Богуш щодо використання усної народної творчості в процесі розвитку мовлення дітей. Так, учена наголошує на тому, що дітям варто пропонувати найкращі зразки народної мудрості - малі фрольклорні жанри: колисанки, забавлянки, утішки, лічилки, примовки, заклички, приспівки, адже саме вони «легкі для наслідування, водночас уводять дитину у світ дорослого побутового життя, прилучають до споконвічних національних цінностей, традицій, звичаїв» [1, с. 12]. За твердженням А. Богуш, діти із задоволенням слухають народні фольклорні твори, вони приваблюють малюків своїм емоційним змістом і змушують прислухатися до звучання рідної мови, збагачувати дитячий словник народними виразами, і це не випадково, «адже всі вони містять надзвичайну образність рідного слова» [1, с. 14]. Упродовж дошкільного віку вчена радить використовувати у спілкуванні з дітьми прислів'я, приказки, примовки й зазначає, що вихователю дошкільного 
закладу варто домагатися, «щоб ці народні перлини стали надбанням дитячого активного словника» [1, с. 14].

Аналіз малих фрольклорних фрорм засвідчив, що їм притаманна низка специфрічних рис, які надзвичайно приваблюють дитину, а саме: невеликий обсяг тексту, доступність змісту, захоплюючий ігровий сюжет, використання художньо-зображальних засобів мови. Фольклорні твори відзначаються барвистістю, виразністю, ритмічністю, легкістю для запам'ятовування.

Висновки. Отже, використання фрольклору, його різноманітних жанрів $є$ ефрективним засобом і важливим чинником успішного навчання дітей діалогічного мовлення, адже скоромовки, мирилки, утішки, лічилки, примовки, заклички збагачують словник учнів новими поняттями, виховують інтерес і любов до рідного слова та забезпечують водночас соціалізацію школярів.

Перспективи подальших досліджень убачаємо в доборі та систематизації українського фрольклору, відповідних вправ і завдань, розробленні методики їх використання в початковій школі з метою фрормування діалогічної компетентності.

\section{БІБЛІОГРАФІЧНИЙ СПИСОК:}

1. Богуш А.М., Лисенко Н.В. Українське народознавство в дошкільному закладі : навчальний посібник. Київ : Вища школа, 1994. 398 с.

2. Вашуленко М.С. Лінгводидактичні орієнтири сучасної початкової мовної освіти в Україні. Вісник Львівського університету. Серія «Філологічна». 2010. Вип. 50. С. 57-65

3. Кротевич Є.В., Родзевич Н.С. Словник лінгвістичних термінів. Київ : Вид-во акад. наук. укр. РСР, 1957. 235 c.

4. Палихата Є.Я. Діалог в усномовленнєвому спілкуванні. Мандрівець. № 1-2. С. 73-78.

5. Сиротинина О.Б. Русская разговорная речь : пособие для учителей. Москва, 1983. 283 с.

6. Скалкин В.Л. Обучение диалогической речи (на материале английского языка) : пособие для учителей. Киев : Рад. шк., 1989. 158 с.

7. Стельмахович М.Г. Народна педагогіка. Київ : Рад. школа, 1985. 312 с. 